\title{
Lamivudine Maintenance Beyond One Year After HBeAg Seroconversion Is a Major Factor for Sustained Virologic Response in HBeAg-Positive Chronic Hepatitis B
}

\author{
Hyun Woong Lee, ${ }^{1-3}$ Heon Ju Lee, ${ }^{3,4}$ Jae Seok Hwang, ${ }^{3,5}$ Joo Hyun Sohn, ${ }^{3,6}$ Jae Young Jang, ${ }^{7}$ Ki Jun Han, ${ }^{8}$ \\ Jun Yong Park, ${ }^{1,3,9}$ Do Young Kim, ${ }^{1,3,9}$ Sang Hoon Ahn,,${ }^{1,3,9}$ Yong Han Paik, ${ }^{1,3,9}$ Chun Kyon Lee, ${ }^{3,10}$ Kwan Sik Lee, ${ }^{1,3,9}$ \\ Chae Yoon Chon, ${ }^{1,3,9}$ and Kwang-Hyub Han ${ }^{1,3,9}$
}

The reported durability of virologic response after successful lamivudine monotherapy is variable, and the question remains as to whether virologic responses can be maintained over an extended follow-up period. The aim of this study was to investigate posttreatment durability, the optimal duration of additional treatment after $\mathrm{HBeAg}$ clearance or seroconversion, and determinants for sustained virologic response (SVR) following lamivudine monotherapy in patients with HBeAg-positive chronic hepatitis B (CHB). From January 1999 to August 2004, 178 Korean patients with $\mathrm{HBeAg}$-positive $\mathrm{CHB}$ were treated with lamivudine and achieved complete responses, defined as a loss of serum $\mathrm{HBeAg}$ and hepatitis B virus DNA, and alanine aminotransferase normalization. The mean duration of lamivudine monotherapy was 26 months (range, 12-77). SVR was maintained in 138 patients (77.5\%). Host and viral factors were compared between 138 patients with SVR and 40 patients whose response was not sustained. The cumulative relapse rates increased from $15.9 \%$ at 1 year to $30.2 \%$ at 5 years, with a mean time to relapse after cessation of lamivudine of 12 months (range, 7-42). Most relapses occurred within 2 years after discontinuation of lamivudine $(33 / 40,82.5 \%)$. On multivariate analysis, age $\leq 40$ years and additional treatment for more than 12 months after $\mathrm{HBeAg}$ clearance or seroconversion were independent factors for SVR. Conclusion: The lamivudine-induced virologic response was durable in patients under 40 years old and those receiving lamivudine for more than 12 months after $\mathrm{HBeAg}$ clearance or seroconversion. Age and additional treatment were major predictive factors for SVR. (HEPATOLOGY 2010;51:415-421.)

Abbreviations: $A L T$, alanine aminotransferase; anti-HBe, hepatitis $B$ virus e antibody; $C H B$, chronic hepatitis $B ; C R$, complete response; $C R F$, case report form; $H B V$, hepatitis $B$ virus; $H C V$, hepatitis $C$ virus; $H D V$, hepatitis $D$ virus; $H I V$, human immunodeficiency virus; IFN- $\alpha$, interferon-alpha; ULN, upper limit of normal; SVR, sustained virologic response.

From the ${ }^{1}$ Department of Internal Medicine, Yonsei University College of Medicine, ${ }^{2}$ Department of Internal Medicine, Chung-Ang University College of Medicine, ${ }^{3}$ Liver Cirrhosis Clinical Research Center, ${ }^{4}$ Department of Internal Medicine, Yeungnam University College of Medicine, ${ }^{5}$ Department of Internal Medicine, Keimyung University School of Medicine, ${ }^{6}$ Department of Internal Medicine, Hanyang University College of Medicine, ${ }^{7}$ Department of Internal Medicine, Soonchunhyang University Hospital, ${ }^{8}$ Department of Internal Medicine, Kwandong University College of Medicine, ${ }^{9} \mathrm{De}-$ partment of Internal Medicine, Yonsei Institute of Gastroenterology, ${ }^{10}$ Department of Internal Medicine, National Health Institute Corporation Ilsan Hospital, Seoul, Korea. Received January 30, 2009; accepted September 10, 2009.

Supported by a grant (no. A050021) of the Good Health R\&D Project, Ministry for Health, Welfare and Family Affairs, Republic of Korea.

Address reprint requests to: Kwang-Hyub Han, Department of Internal Medicine, Yonsei University College of Medicine, 250 Seongsanno, Seodaimun-gu, Seoul 120752, Korea. E-mail: gihankhys@yuhs.ac; fax: 82-2-312-7833 Copyright $(2009$ by the American Association for the Study of Liver Diseases. Published online in Wiley InterScience (www.interscience.wiley.com). DOI 10.1002/hep.23323

Potential conflict of interest: Nothing to report.

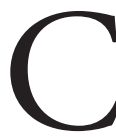

urrently, a number of therapies for chronic hepatitis $\mathrm{B}(\mathrm{CHB})$ have been developed: interferonalpha (IFN- $\alpha$ ), lamivudine, adefovir dipivoxil, entecavir, tenofovir, and pegylated interferon-alpha (pegIFN- $\alpha)^{1}{ }^{1-3}$ Although they can all be considered firstline therapies for individuals with noncirrhotic liver disease, the degree of viral suppression achieved during treatment and the durability of response after treatment cessation appear to be the most important determinants of drug selection.

However, achieving a durable response has been hampered by drug resistance and the limited efficacy of antiviral agents. Since its introduction in the late 1990s, lamivudine has remained an important therapy for $\mathrm{CHB}$, with many doctors and most patients opting for lamivudine rather than IFN- $\alpha{ }^{4-9}$ However, the efficacy of lamivudine is limited by the emergence of drug-resistant hepatitis $\mathrm{B}$ virus (HBV) mutants, restricting its use as a long-term therapy. ${ }^{10-13}$ Additionally, relapses after discontinuing antiviral therapy occur in a sizeable proportion of patients. Although there are no robust comparative data, the durability 
of lamivudine treatment is generally considered to be less than that of IFN- $\alpha .{ }^{14}$ Furthermore, studies of lamivudine treatment in Korean patients have reported lower rates of durability compared with studies of patients in Western countries. ${ }^{15,16}$

Thus, there remain a number of questions regarding lamivudine therapy for $\mathrm{CHB}$ in terms of the appropriate duration of treatment, continuation of treatment after $\mathrm{HBeAg}$ seroconversion, and predictive factors for sustained $\mathrm{HBeAg}$ seroconversion. Recently, several factors have been reported to be associated with increased durability of lamivudine therapy, including longer duration of consolidation treatment, younger age, lower HBV DNA level at the time treatment was stopped, and genotype B. ${ }^{15,17-20}$ On the basis of these reports, the current American Association for the Study of Liver Diseases (AASLD) guidelines recommend that treatment should be continued until the patient has achieved $\mathrm{HBeAg}$ seroconversion and completed at least 6 months of additional treatment after the appearance of anti-HBe in patients with $\mathrm{HBeAg}$ positive CHB. ${ }^{21}$ However, the number of patients in these studies was small (under 100) and the duration of the follow-up period was short ( $<3$ years).

This retrospective analysis of a large multicenter cohort of Korean patients with $\mathrm{HBeAg}$-positive $\mathrm{CHB}$ (predominantly genotype $\mathrm{C}$ ) investigated posttreatment durability, the optimal duration of additional treatment after $\mathrm{HBeAg}$ clearance or seroconversion, and determinants for sustained virologic response (SVR) following lamivudine monotherapy.

\section{Patients and Methods}

Patients. From January 1999 to August 2004, a total of 748 patients with $\mathrm{HBeAg}$-positive $\mathrm{CHB}$ infection were treated with lamivudine. This study was a retrospective, multicenter trial. All patients were recruited from seven medical institutions in Korea. Patients enrolled in this study met the following entry criteria: they were 18-75 years of age, the presence of serum HBsAg and $\mathrm{HBeAg}$ was observed for at least 6 months, they had elevated serum alanine aminotransferase (ALT) on two occasions, and the presence of HBV DNA had been documented on two occasions. Candidates were required to have compensated liver disease. Consecutive patients were treated with lamivudine for at least 12 months. The exclusion criteria were as follows: the presence of antibody to human immunodeficiency virus (HIV), hepatitis C virus (HCV) or hepatitis D virus (HDV), a history of malignancy, or evidence of other forms of liver disease.

Complete response (CR) was defined as normalization of serum ALT level, loss of serum HBV DNA, as deter- mined using the Digene Hybrid Capture II HBV DNA Test (Digene, Gaithersburg, MD; cutoff value $=1.4 \times$ $10^{5}$ copies $/ \mathrm{mL}$ ), and HBeAg clearance (Abbott Diagnostics, Wiesbaden, Germany). According to the 2004 AASLD guidelines, patients in whom HBeAg seroconversion had occurred were maintained on treatment for $>3$ months after seroconversion was confirmed. In patients who had developed only clearance, treatment was also continued for $>3$ months after clearance, differing from the continuation-of-treatment recommended in the guidelines. CR was achieved in 287 of 748 patients (38.4\%). Of these 287 patients, 178 patients were followed for at least 6 months and discontinued lamivudine treatment after CR, whereas 109 patients continued lamivudine treatment after CR. However, 101 of 748 patients (13.2\%) were lost to follow-up. In 360 of 748 patients (48.1\%), lamivudine was switched to a new antiviral agent or a new viral agent was added, due to primary nonresponse or virologic breakthrough (Fig. 1).

Methods. Serum HBeAg, anti-HBe, HBV DNA, and ALT were tested every 3-6 months during lamivudine therapy (or as necessary) and after drug cessation. Patients who maintained CR for more than 6 months after cessation of lamivudine therapy were classified as having SVR. Relapsers were defined as patients with reappearance of serum HBV DNA after drug cessation. The cumulative relapse rates and the predictors for SVR were evaluated.

Statistical Analyses. Data are expressed as means \pm standard error or median (range). Student's $t$-test, Fisher's exact test, and the chi-squared test were used for comparisons of variables between groups. The Kaplan-Meier method was used to calculate the cumulative rates of relapse. To determine predictive factors for SVR, multivariate analysis using Cox's regression model was performed. Statistical analysis was performed using Statistical Package for Social Science software v. 12.0 (SPSS, Chicago, IL). A $P$-value less than 0.05 was deemed statistically significant.

\section{Results}

Patient Characteristics. Of the patients, 178 were followed for at least 6 months and discontinued lamivudine treatment after CR. The characteristics at baseline are shown in Table 1; 129 (72.5\%) patients were male, and the mean age was 39 years (range, 21-71). The mean baseline serum ALT level was 265.1 IU/L (range, 48678). The mean baseline serum HBV DNA level was 7.8 $\log _{10}$ copies/mL (range, 5.2-9.4). The mean duration of lamivudine treatment was 26 months (range, 12-77), and the mean total follow-up period was 53 months (range, 24-90). 


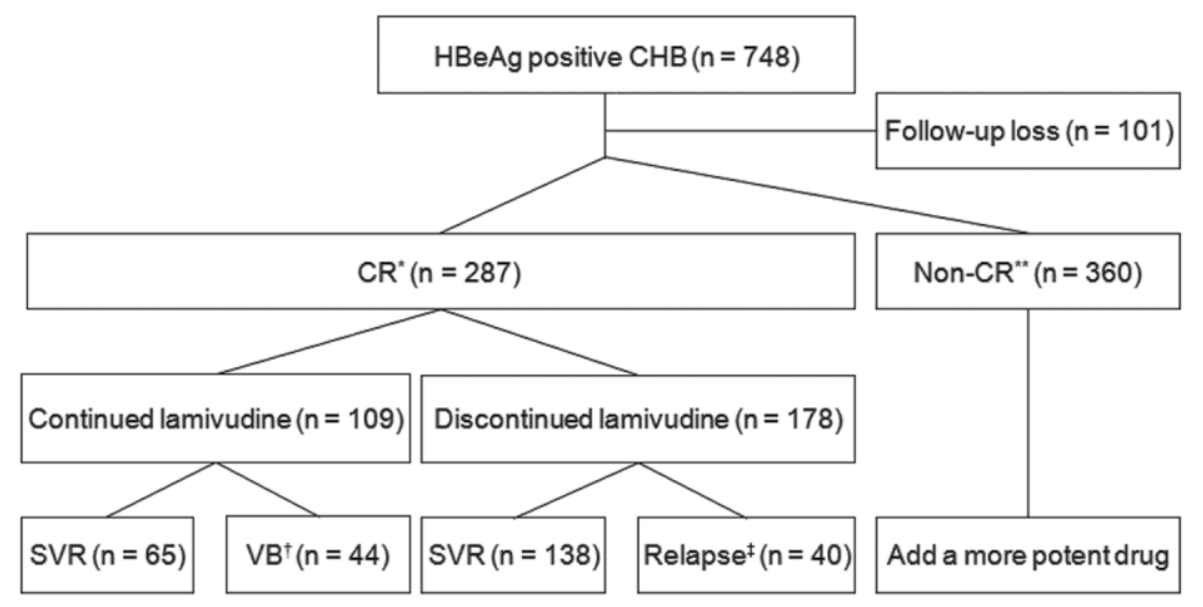

Fig. 1. Clinical outcomes in 748 patients with HBeAg-positive CHB treated with lamivudine monotherapy. The figure shows the flow diagram for 748 patients enrolled in the present study. ${ }^{*}$ Complete response was defined as normalization of serum ALT level, Ioss of serum HBV DNA (cutoff value $=1.4 \times 10^{5}$ copies $/ \mathrm{mL}$ ), and $\mathrm{HBeAg}$ clearance. ${ }^{* *}$ Noncomplete response was defined as primary nonresponse and virologic breakthrough. †Virologic breakthrough was defined as reappearance of serum HBV DNA (cutoff value $=300 \mathrm{copies} / \mathrm{mL}$ ) while on treatment, after achieving CR in a medication-compliant patient. $\ddagger$ Relapse was defined as reappearance of serum HBV DNA (cutoff value $=1.4 \times 10^{5} \mathrm{copies} / \mathrm{mL}$ ) after drug cessation. Abbreviations: CHB, chronic hepatitis B; CR, complete response; SVR, sustained virologic response; VB, virologic breakthrough.

Long-Term Clinical Outcomes. Among 178 patients who discontinued lamivudine treatment after CR, 138 patients $(77.5 \%)$ maintained SVR. The mean times to $\mathrm{HBeAg}$ clearance and seroconversion were 13 months (range, 3-36) and 16 months (range, 3-36), respectively. The cumulative relapse rates at $1,2,3,4$, and 5 years were $15.9 \%, 23.0 \%, 26.4 \%, 30.2 \%$, and $30.2 \%$, respectively (Fig. 2A). The mean time to relapse after cessation of lamivudine was 12 months (range, 7-42). Most relapses occurred within 2 years after discontinuation of lamivudine $(33 / 40,82.5 \%)$.

Table 1. Baseline Characteristics of the Patients

\begin{tabular}{lc}
\hline \multicolumn{1}{c}{ Characteristic } & $\begin{array}{c}\text { HBeAg (+) CHB } \\
\mathbf{n = 1 7 8}(\%)\end{array}$ \\
\hline Male:female & $129: 49$ \\
Mean age (years) & $39.0 \pm 10.3$ \\
$\leq 40$ & $101(56.7)$ \\
$>40$ & $77(43.3)$ \\
Mean serum ALT (IU/L) & $225.3(48-678)$ \\
$>1$ and $\leq 2$ times ULN* & $14(7.9)$ \\
$>2$ and $\leq 5$ times ULN* & $73(41.0)$ \\
$>5$ and $\leq 10$ times ULN* & $61(34.3)$ \\
$>10$ and $<20$ times ULN* & $30(16.9)$ \\
Mean serum HBV DNA (log 10 copies/mL) & $7.8 \pm 1.0(5.2-9.4)$ \\
$\leq 8.0$ & $94(52.8)$ \\
$>8.0$ & $84(47.2)$ \\
Family history of CHB & $56(31.5)$ \\
Previous IFN- $\alpha$ therapy & $17(9.6)$ \\
Mean treatment duration, months (range) & $26(12-77)$ \\
Mean total follow-up duration, months (range) & $53(24-90)$ \\
\hline
\end{tabular}

Values are expressed as mean \pm standard error of the mean.

*The upper limit of normal ALT levels is less than $40 \mathrm{IU} / \mathrm{L}$.

Abbreviations: $\mathrm{HBeAg}(+), \mathrm{HBeAg}$ positive; $\mathrm{CHB}$, chronic hepatitis B; ALT, alanine aminotransferase; HBV, hepatitis B virus; ULN, upper limit of normal; IFN- $\alpha$, interferon alpha.
Of patients with HBeAg clearance only, 25 (14\%) were followed up. Of them, eight patients relapsed, with virologic breakthrough, and 17 patients showed SVR. HBeAg had reverted to positive in six patients and two patients progressed to $\mathrm{HBeAg}$-negative $\mathrm{CHB}$. Thus, the posttreatment durability of $\mathrm{HBeAg}$ clearance alone upon discontinuation of lamivudine was $68 \%(17 / 25)$ at 5 years.

Patients with $\mathrm{HBeAg}$ seroconversion $(\mathrm{n}=153)$ were also followed. The cumulative relapse rates at 1, 2, 3, 4, and 5 years were from $13.6 \%$ at 1 year to $28.3 \%$ at 5 years (Fig. 2B). Of these, 32 patients relapsed with virologic breakthrough and 121 patients showed SVR. HBeAg reverted to positive in 25 patients and seven patients progressed to $\mathrm{HBeAg}$-negative $\mathrm{CHB}$.

\section{Predictive Factors of Sustained Virologic Response.} Differences between the 40 patients with relapse and 138 patients with SVR in terms of age, baseline ALT, and baseline HBV DNA were investigated. In univariate analysis, significant predictive factors for SVR were age (years; mean, $41.8 \pm 11.1$ vs. $38.1 \pm 10.0 ; P=0.048)$, baseline serum ALT (IU/L; mean, $215.5 \pm 155.1$ vs. $279.5 \pm$ 240.4; $P=0.048$ ), additional treatment duration after HBeAg clearance (months; mean, $7.9 \pm 7.0$ vs. $17.9 \pm$ 12.4; $P<0.001$ ), and additional treatment duration after $\mathrm{HBeAg}$ seroconversion (months; mean, $7.1 \pm 5.9$ vs. $14.1 \pm 11.6 ; P<0.001)$. In particular, when the duration of additional lamivudine treatment after $\mathrm{HBeAg}$ clearance or seroconversion was stratified into 6- and 12month intervals, the cumulative relapse rates were significantly lower in patients with an additional treatment duration of $\geq 12$ months $(P<0.001)$. Gender, baseline 

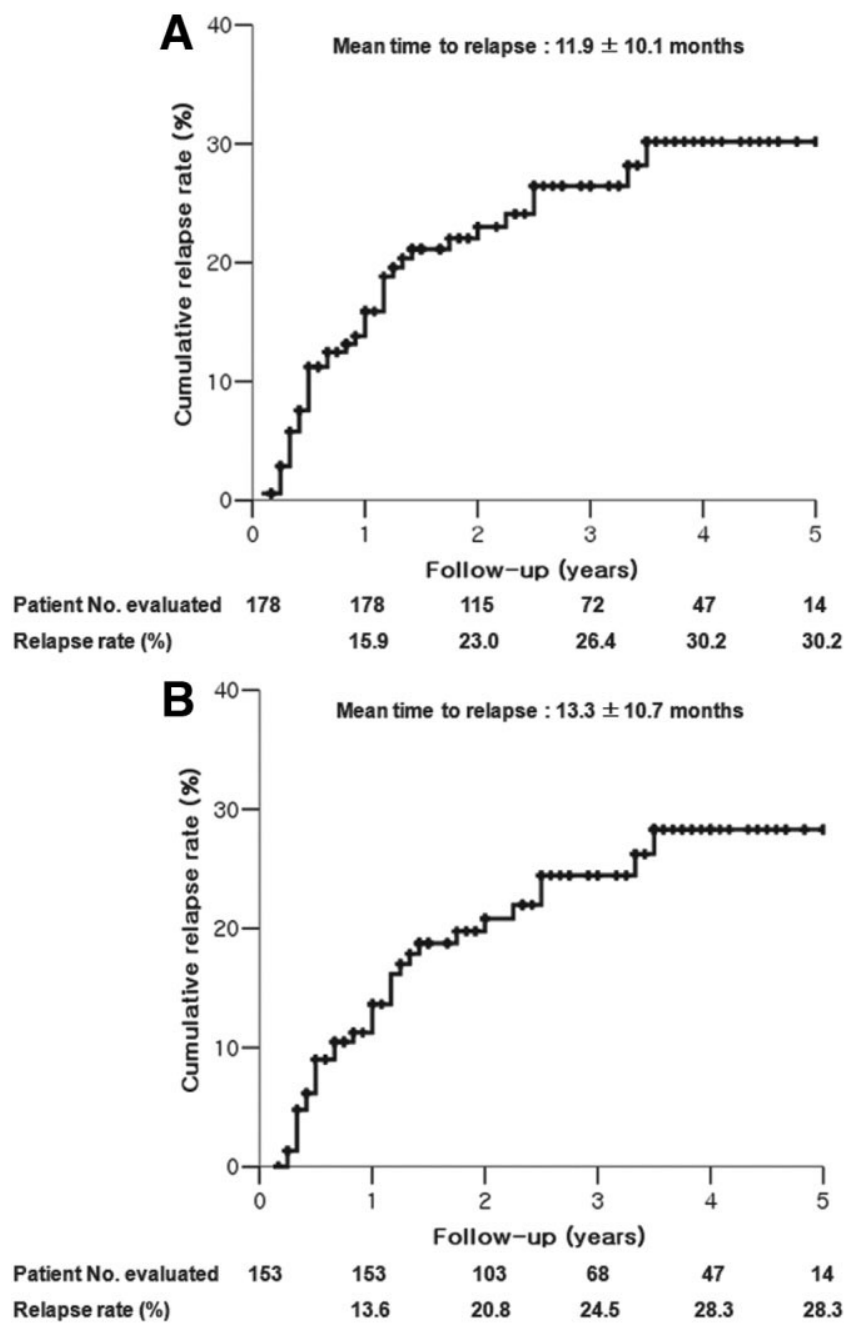

Fig. 2. Among (A) 178 patients who discontinued lamivudine monotherapy after CR the cumulative relapse rate increased from $15.9 \%$ at 1 year to $30.2 \%$ at 5 years. $\mathrm{HBeAg}$ seroconversion was observed in (B) 153 patients. Among them the cumulative relapse rate increased from $13.6 \%$ at 1 year to $28.3 \%$ at 5 years.

HBV DNA, family history, and previous INF- $\alpha$ treatment were not significantly different between patients with relapse and SVR (Table 2).

Multivariate Cox regression analysis revealed that patients with age $\leq 40$ years (odds ratio $[\mathrm{OR}], 1.950 ; 95 \%$ confidence interval [CI], 1.031-3.689; $P=0.040$ ), additional treatment duration after $\mathrm{HBeAg}$ clearance $\geq 12$ months (OR, 9.259; 95\% CI, 4.184-20.408; $P<0.001$ ), and additional treatment duration after $\mathrm{HBeAg}$ seroconversion $\geq 12$ months (OR, 14.292; 95\% CI, 6.79134.285; $P<0.001)$ were independent determinants of SVR (Table 3).

At 5 years the cumulative relapse rates were higher in patients $>40$ years ( $\leq 40$ vs. $>40$ years, $24.6 \%$ vs. $36.9 \%$; $P=0.039$; Fig. $3 \mathrm{~A}$ ) and those with additional treatment duration after HBeAg clearance of $<12$ months ( $<12$ vs. $\geq 12$ months, $61.9 \%$ vs. $8.7 \%$; $P<0.001$; Fig. $3 \mathrm{~B}$ ).
Continuation of Lamivudine Treatment. Among 287 patients with CR, 109 patients received prolonged lamivudine therapy after CR (Fig. 1). Sixty-five (59.6\%) patients maintained undetectable HBV DNA by polymerase chain reaction $(\mathrm{PCR})(<300$ copies $/ \mathrm{mL})$ at the time of last follow-up (mean total follow-up duration, 51.8 months), whereas 44 (40.4\%) patients had detectable HBV DNA after CR. Among 44 patients, 21 patients developed virologic breakthrough along with lamivudineresistant mutations during an additional treatment for a median duration of 33 months (range, 5-83). Of the 21 patients with a lamivudine-resistant mutation, 12 patients had both rtM204I and rtL180M mutations, six patients had both rtM204V and rtL180M mutations, and three patients had the rtM204I mutation only.

\section{Discussion}

Spontaneous $\mathrm{HBeAg}$ clearance and seroconversion predict long-lasting suppression of $\mathrm{HBV}$, reduced infectivity, and improved clinical prognosis. Thus, lamivudine-induced $\mathrm{HBeAg}$ clearance and seroconversion have been considered a potential endpoint for stopping antiviral treatment. ${ }^{22}$ Although long-term lamivudine therapy increases $\mathrm{HBeAg}$ clearance and/or seroconversion rates, there is still a risk of increased frequency of virologic breakthrough. ${ }^{23,24}$ Additionally, lamivudine-induced $\mathrm{HBeAg}$ clearance or seroconversion is not durable in Asian patients, and viral relapse occurs more frequently in patients with a shorter duration of additional lamivudine therapy after HBeAg clearance or seroconversion. ${ }^{15,16,18}$ Thus, the optimal duration of lamivudine therapy has yet to be determined.

In accordance with the AASLD practice guidelines, $\mathrm{HBeAg}$ seroconversion remains the most desirable endpoint for the treatment of $\mathrm{HBeAg}$-positive $\mathrm{CHB}$, although other treatment endpoints in some clinical studies have included undetectable levels of HBV DNA, normalization of serum ALT, and HBeAg clearance. ${ }^{21,25,26} \mathrm{~A}$ longer duration of consolidation lamivudine therapy after both $\mathrm{HBeAg}$ clearance and seroconversion was strongly associated with the probability of SVR. More precisely, additional lamivudine treatment for $\geq 12$ months after $\mathrm{HBeAg}$ seroconversion was a stronger predictor than that after $\mathrm{HBeAg}$ clearance (OR 14.292 vs. 9.259). Both $\mathrm{HBeAg}$ clearance and seroconversion were appropriate parameters for the cessation of lamivudine in this study. Our data suggest that prolonged additional therapy (i.e., $\geq 12$ months after HBeAg clearance or seroconversion) might be needed to achieve SVR in Asian patients. As most relapses occurred within 2 years after discontinuation of lamivudine (82.5\%), our results also suggest that patients with $\mathrm{HBeAg}$ clearance should be closely moni- 
Table 2. Univariate Analysis of Predictive Factors for Sustained Virologic Response Among 178 Patients Who Stopped Lamivudine After Complete Response

\begin{tabular}{|c|c|c|c|}
\hline Variable & Relapser* $n=40(\%)$ & SVR $^{\dagger} n=138(\%)$ & $P$ Value \\
\hline Male:female & $32: 8$ & $97: 41$ & 0.226 \\
\hline Mean age (years) & $41.8 \pm 11.1$ & $38.1 \pm 10.0$ & 0.048 \\
\hline$\leq 40$ & $17(42.5)$ & $84(60.9)$ & \\
\hline$>40$ & $23(57.5)$ & $54(39.1)$ & 0.039 \\
\hline Baseline serum ALT (IU/L) & $215.5 \pm 155.1$ & $279.5 \pm 240.4$ & 0.048 \\
\hline$>1$ and $\leq 2$ times ULN $\ddagger$ & $3(7.5)$ & $11(8.0)$ & \\
\hline$>2$ and $\leq 5$ times ULN $\ddagger$ & $22(55.0)$ & $51(37.0)$ & \\
\hline$>5$ and $\leq 10$ times ULN $\ddagger$ & $8(20.0)$ & $53(38.4)$ & \\
\hline$>10$ and $<20$ times ULN $\ddagger$ & $7(17.5)$ & $23(16.7)$ & 0.136 \\
\hline Baseline HBV DNA ( $\log _{10}$ copies $/ \mathrm{mL}$ ) & $7.9 \pm 1.0$ & $7.7 \pm 1.0$ & 0.334 \\
\hline$\leq 8.0$ & $19(47.5)$ & $75(54.4)$ & \\
\hline$>8.0$ & $21(52.5)$ & $63(45.7)$ & 0.445 \\
\hline Family history of $\mathrm{CHB}$ & $12(30.8)$ & $44(32.1)$ & 0.873 \\
\hline Previous IFN- $\alpha$ therapy & $6(15.4)$ & $11(8.0)$ & 0.170 \\
\hline HBeAg seroconversion & $32(80.0)$ & $121(87.7)$ & 0.218 \\
\hline \multicolumn{4}{|c|}{ Mean additional treatment duration after $\mathrm{HBeAg}$} \\
\hline clearance (months) & $7.9 \pm 7.0$ & $17.9 \pm 12.4$ & $<0.001$ \\
\hline$<6$ vs. $\geq 6$ & $12: 28(30.0: 70.0)$ & $24: 114(17.4: 82.6)$ & 0.080 \\
\hline$<12$ vs. $\geq 12$ & $32: 8(80.0: 20.0)$ & $29: 109(21.0: 79.0)$ & $<0.001$ \\
\hline \multicolumn{4}{|c|}{ Mean additional treatment duration after $\mathrm{HBeAg}$} \\
\hline seroconversion (months) & $7.1 \pm 5.9$ & $14.1 \pm 11.6$ & $<0.001$ \\
\hline$<6$ vs. $\geq 6$ & $13: 19(40.6: 59.4)$ & $22: 99(18.2: 81.8)$ & 0.007 \\
\hline$<12$ vs. $\geq 12$ & $22: 10(68.8: 31.3)$ & $36: 85(29.8: 70.2)$ & $<0.001$ \\
\hline
\end{tabular}

*Relapsers were defined as patients having reappearance of serum HBV DNA after drug cessation.

†Sustained virologic response (SVR) was defined as a complete response sustained $>6$ months after the end of lamivudine therapy.

$\ddagger$ The upper limit of normal ALT levels is less than $40 \mathrm{IU} / \mathrm{L}$.

Abbreviations: ALT, alanine aminotransferase; HBV, hepatitis B virus; ULN, upper limit of normal; IFN- $\alpha$, interferon alpha.

Table 3. Multivariate Cox Regression Analysis of Predictive Factors Associated with Sustained Virologic Response

\begin{tabular}{lccr}
\hline \multicolumn{1}{c}{ Variable } & Odds Ratio & 95\% Cl & P Value \\
\hline Age (years) & & & \\
$\leq 40$ & 1.950 & $1.031-3.689$ & 0.040 \\
$\quad>40$ & 1.0 & & \\
Baseline serum ALT (IU/L) & & & \\
$>1$ and $\leq 2$ times ULN* & 1.0 & & 0.120 \\
$>2$ and $\leq 5$ times ULN* & 2.623 & $0.777-8.853$ & 0.587 \\
$>5$ and $\leq 10$ times ULN* & 1.452 & $0.378-5.586$ & \\
$>10$ and $<20$ times ULN* & 2.573 & $0.653-10.148$ & 0.177 \\
Baseline serum HBV DNA & & & \\
$\quad$ (log 10 copies/mL) & & & \\
$\leq 8.0$ & 1.0 & & \\
$>8.0$ & 1.462 & $0.771-2.773$ & \\
Additional treatment duration & & & \\
$\quad$ after HBeAg & & & \\
$\quad$ clearance(months) & & & \\
$<12$ & 1.0 & & \\
$\geq 12$ & 9.259 & $4.184-20.408$ & $<0.001$ \\
Additional treatment duration & & & \\
$\quad$ after HBeAg & & & \\
$\quad$ Seroconversion (months) & & & \\
$<12$ & 1.0 & $6.791-34.285$ & \\
$\geq 12$ & 14.292 & & \\
\hline
\end{tabular}

* The upper limit of normal ALT levels is less than $40 \mathrm{IU} / \mathrm{L}$.

Abbreviations: ALT, alanine aminotransferase; HBV, hepatitis B virus; ULN, upper limit of normal. tored for relapse with follow-up testing of HBV DNA and $\mathrm{HBeAg}$ for up to 2 years after discontinuation of lamivudine monotherapy.

Several reports have evaluated the durability of $\mathrm{HBeAg}$ seroconversion with lamivudine therapy, resulting in a wide range of durable HBeAg seroconversion rates. ${ }^{14,27}$ In a study by van Nunen et al., ${ }^{14}$ the relapse rates after $\mathrm{HBeAg}$ seroconversion were reported as $42 \%$ and $54 \%$ after 1 and 3 years, respectively. Song et al. ${ }^{15}$ also reported high relapse rates, of $36 \%$ and $49 \%$ after 1 and 2 years, respectively. Our results $(13.6 \%$ at 1 year to $28.3 \%$ at 5 years), in contrast, are more similar to those reported by Dienstag et al., ${ }^{27}$ with 1 - and 3-year relapse rates of $14 \%$ and $28 \%$, respectively. It is difficult to explain these disparate results. However, differences in the duration of lamivudine therapy may partially account for the different relapse rates. The lamivudine treatment duration for subjects in the van Nunen et al. and Song et al. studies was as short as 6 months for some subjects, whereas the minimum duration of therapy in the study by Dienstag et al. and our study was 12 months. ${ }^{14,15,27}$ Thus, the longer duration of treatment may have resulted in lower relapse rates.

Data from this Korean cohort indicate that the durability of $\mathrm{HBeAg}$ seroconversion in patients with $\mathrm{CHB}$ was similar to the durability of $\approx 70 \%$ reported in non-Asian 

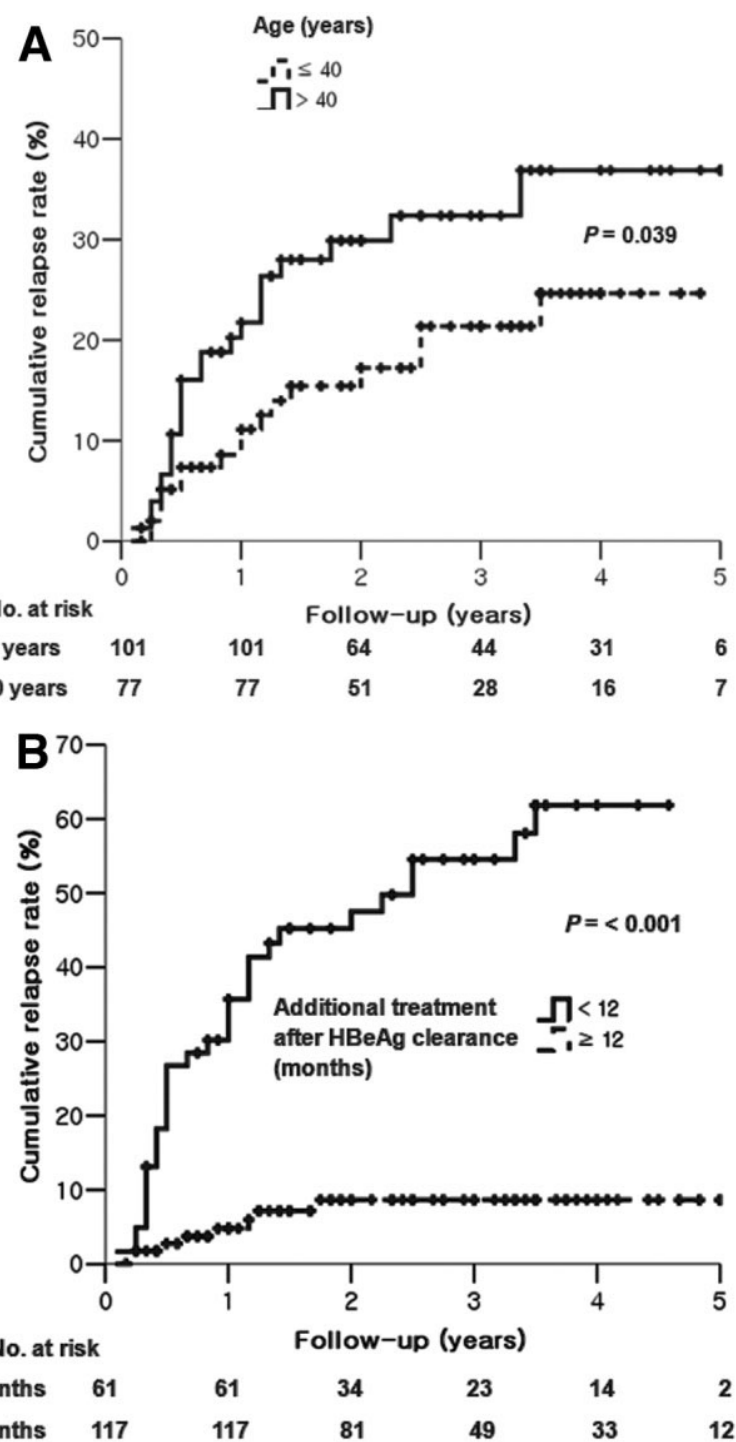

Fig. 3. The cumulative relapse rates were higher in (A) patients $>40$ years ( $\leq 40$ vs. $>40$ years, $24.6 \%$ vs. $36.9 \% ; P=0.039$ ) and (B) those with additional treatment duration after HBeAg clearance $<12$ months ( $<12$ vs. $\geq 12$ months, $61.9 \%$ vs. $8.7 \%$; $P<0.001$ ).

patients. ${ }^{27}$ Other Korean studies have reported lower rates of durability (50\%-60\%), which may in part be related to small patient numbers, and/or shorter duration of treatment before and after HBeAg seroconversion. ${ }^{15-19}$

SVR was previously found to be associated with longer duration of additional treatment, younger age, lower HBV DNA level at the time treatment was stopped, and genotype B. ${ }^{15,17-20}$ However, the number of patients in these studies was smaller than in our study (under 100 vs. 178 patients). Also, the duration of treatment and additional treatment after HBeAg seroconversion were shorter than in our study (mean 13 vs. 26 months and mean 4.5 vs. 12.4 months, respectively). In our study, age and the duration of additional lamivudine treatment after $\mathrm{HBeAg}$ clearance or seroconversion were predictive factors for SVR.
A major limitation of this multicenter, large-scale cohort study was the use of a relatively insensitive HBV DNA assay. It is possible that this low sensitivity was partly responsible for the apparent relatively low relapse rates after CR. More sensitive HBV DNA assays would be required to evaluate this issue definitively.

We subanalyzed 51 patients with SVR who had been followed for more than 4 years after 2004, using a more sensitive assay (the COBAS TaqMan 48 analyzer, Roche Molecular Systems, Branchburg, NJ; with a lower limit of detection of 300 copies/mL). The mean HBV DNA level was 429 copies/mL (range, <300-1,296). The percentage of relapse could have been higher if more sensitive HBV DNA assays had been used during the study period. However, there was no virological rebound (HBV DNA level $>10,000$ copies $/ \mathrm{mL}$ ) in 51 patients who completed at least 12 months of additional treatment after $\mathrm{HBeAg}$ clearance or seroconversion.

Interestingly, despite prolonged lamivudine treatment after CR, 21 of 109 (19.3\%) patients experienced lamivudine-resistant mutations and virologic breakthrough. These data suggest that lamivudine could be stopped after optimal additional treatment in patients who have achieved HBeAg clearance or seroconversion. However, additional studies are needed because new antiviral agents that have low resistance and more potent antiviral efficacy could provide different insights into prolonged therapy.

In conclusion, the lamivudine-induced virologic response was durable in patients under 40 years old and receiving lamivudine for more than 12 months after $\mathrm{HBeAg}$ clearance or seroconversion in $\mathrm{CHB}$ that was predominantly genotype C. Future long-term prospective and comparative data are needed to evaluate the durability of lamivudine-induced HBeAg clearance or seroconversion according to HBV genotype, given the continuing use of long-term lamivudine monotherapy in the management of CHB.

Acknowledgment: The English in this document was checked by at least two professional editors, both native speakers of English. For a certificate, see: http://www. textcheck.com/certificate/8QkxbA

\section{References}

1. Keeffe EB, Dieterich DT, Han SH, Jacobson IM, Martin P, Schiff ER, et al. A treatment algorithm for the management of chronic hepatitis $\mathrm{B}$ virus infection in the United States: an update. Clin Gastroenterol Hepatol 2006; 4:936-962.

2. Fung SK, Chae HB, Fontana RJ, Conjeevaram H, Marrero J, Oberhelman $\mathrm{K}$, et al. Virologic response and resistance to adefovir in patients with chronic hepatitis B. J Hepatol 2006;44:283-290.

3. Chang TT, Gish RG, de Man R, Gadano A, Sollano J, Chao YC, et al. A comparison of entecavir and lamivudine for $\mathrm{HBeAg}$-positive chronic hepatitis B. N Engl J Med 2006;354:1001-1010. 
4. Yuen MF, Hui CK, Cheng CC, Wu CH, Lai YP, Lai CL. Long-term follow-up of interferon alfa treatment in Chinese patients with chronic hepatitis B infection: the effect on hepatitis B e antigen seroconversion and the development of cirrhosis-related complications. Hepatology 2001; 34:139-145.

5. Kao JH, Wu NH, Chen PJ, Lai MY, Chen DS. Hepatitis B genotypes and the response to interferon therapy. J Hepatol 2000;33:998-1002.

6. Zhang X, Zoulim F, Habersetzer F, Xiong S, Trepo C. Analysis of hepatitis $\mathrm{B}$ virus genotypes and pre-core region variability during interferon treatment of HBe antigen negative chronic hepatitis B. J Med Virol 1996;48: 8-16.

7. Dienstag JL, Schiff ER, Wright TL, Perrillo RP, Hann HW, Goodman Z, et al. Lamivudine as initial treatment for chronic hepatitis B in the United States. N Engl J Med 1999;341:1256-1263.

8. Lai CL, Chien RN, Leung NW, Chang TT, Guan R, Tai DI, et al. A one-year trial of lamivudine for chronic hepatitis B. Asia Hepatitis Lamivudine Study Group. N Engl J Med 1998;339:61-68.

9. Schalm SW, Heathcote J, Cianciara J, Farrell G, Sherman M, Willems B, et al. Lamivudine and alpha interferon combination treatment of patients with chronic hepatitis B infection: a randomised trial. Gut 2000;46:562568.

10. Allen MI, Deslauriers M, Andrews CW, Tipples GA, Walters KA, Tyrrell $\mathrm{DL}$, et al. Identification and characterization of mutations in hepatitis $\mathrm{B}$ virus resistant to lamivudine. Lamivudine Clinical Investigation Group. HePATOLOGY 1998;27:1670-1677.

11. Stuyver LJ, Locarnini SA, Lok A, Richman DD, Carman WF, Dienstag JL, et al. Nomenclature for antiviral-resistant human hepatitis B virus mutations in the polymerase region. Hepatology 2001;33:751-757.

12. Chang TT, Lai CL, Chien RN, Guan R, Lim SG, Lee CM, et al. Four years of lamivudine treatment in Chinese patients with chronic hepatitis B. J Gastroenterol Hepatol 2004;19:1276-1282.

13. Lok AS, Lai CL, Leung N, Yao GB, Cui ZY, Schiff ER, et al. Long-term safety of lamivudine treatment in patients with chronic hepatitis B. Gastroenterology 2003;125:1714-1722.

14. van Nunen AB, Hansen BE, Suh DJ, Lohr HF, Chemello L, Fontaine H, et al. Durability of $\mathrm{HBeAg}$ seroconversion following antiviral therapy for chronic hepatitis B: relation to type of therapy and pretreatment serum hepatitis B virus DNA and alanine aminotransferase. Gut 2003;52:420-424.

15. Song BC, Suh DJ, Lee HC, Chung YH, Lee YS. Hepatitis B e antigen seroconversion after lamivudine therapy is not durable in patients with chronic hepatitis B in Korea. HePATOLOGY 2000;32:803-806.
16. Yoon SK, Jang JW, Kim CW, Bae SH, Choi JY, Choi SW, et al. Long-term results of lamivudine monotherapy in Korean patients with $\mathrm{HBeAg}$-positive chronic hepatitis $\mathrm{B}$ : response and relapse rates, and factors related to durability of HBeAg seroconversion. Intervirology 2005;48:341-349.

17. Lee KM, Cho SW, Kim SW, Kim HJ, Hahm KB, Kim JH. Effect of virological response on post-treatment durability of lamivudine-induced HBeAg seroconversion. J Viral Hepat 2002;9:208-212.

18. Ryu SH, Chung YH, Choi MH, Kim JA, Shin JW, Jang MK, et al. Long-term additional lamivudine therapy enhances durability of lamivudine-induced HBeAg loss: a prospective study. J Hepatol 2003;39:614619.

19. Lee HC, Suh DJ, Ryu SH, Kim H, Shin JW, Lim YS, et al. Quantitative polymerase chain reaction assay for serum hepatitis $\mathrm{B}$ virus DNA as a predictive factor for post-treatment relapse after lamivudine induced hepatitis B e antigen loss or seroconversion. Gut 2003;52:1779-1783.

20. Chien RN, Yeh CT, Tsai SL, Chu CM, Liaw YF. Determinants for sustained HBeAg response to lamivudine therapy. HePATOlogy 2003;38: 1267-1273.

21. Lok AS, McMahon BJ. Chronic hepatitis B. Hepatology. 2007;45:507539.

22. Dienstag JL, Schiff ER, Mitchell M, Casey DE Jr, Gitlin N, Lissoos T, et al. Extended lamivudine retreatment for chronic hepatitis B: maintenance of viral suppression after discontinuation of therapy. HePATOLOGY 1999; 30:1082-1087.

23. Liaw YF, Leung NW, Chang TT, Guan R, Tai DI, Ng KY, et al. Effects of extended lamivudine therapy in Asian patients with chronic hepatitis B. Asia Hepatitis Lamivudine Study Group. Gastroenterology 2000;119:172-180.

24. Leung NW, Lai CL, Chang TT, Guan R, Lee CM, Ng KY, et al. Extended lamivudine treatment in patients with chronic hepatitis B enhances hepatitis $B$ e antigen seroconversion rates: results after 3 years of therapy. HEPATOLOGY 2001;33:1527-1532.

25. Keeffe EB, Dieterich DT, Han SH, Jacobson IM, Martin P, Schiff ER, et al. A treatment algorithm for the management of chronic hepatitis $\mathrm{B}$ virus infection in the United States: an update. Clin Gastroenterol Hepatol 2006;4:936-962.

26. Marcellin P, Chang TT, Lim SG, Tong MJ, Sievert W, Shiffman ML, et al; Adefovir Dipivoxil 437 Study Group. Adefovir dipivoxil for the treatment of hepatitis B e antigen-positive chronic hepatitis B. N Engl J Med. 2003; 348:808-816.

27. Dienstag JL, Cianciara J, Karayalcin S, Kowdley KV, Willems B, Plisek S, et al. Durability of serologic response after lamivudine treatment of chronic hepatitis B. HePATOLOGY 2003;37:748-755. 